http://dx.doi.org/10.18778/1508-1117.26.07

Matgorzata Dworak, Paulina Tobiasz-Lis

\title{
WSPÓŁCZESNE ZNACZENIE DZIEDZICTWA PRZEMYSLOWEGO W DOLINIE RZEKI KAMIENNEJ (WOJ. ŚWIĘTOKRZYSKIE)
}

Zarys treści Przedmiotem opracowania jest materialne dziedzictwo przemysłowe w dolinie rzeki Kamiennej, położonej w województwie świętokrzyskim oraz jego współczesne znaczenie w zagospodarowaniu przestrzeni obszaru. Zasadniczą część artykułu poświęconą wykorzystaniu obiektów poprzemysłowych w obecnych uwarunkowaniach społeczno-gospodarczych, poprzedzono krótką charakterystyką etapów i czynników rozwoju działalności przemysłowej na tym terenie. W ostatniej części opracowania zaprezentowano wyniki badań ankietowych dotyczących społecznej percepcji przemysłowej przeszłości regionu i opinii na temat adaptacji obiektów poprzemysłowych do pełnienia nowych funkcji.

Słowa kluczowe Przemysł, dziedzictwo przemysłowe, rzeka Kamienna, województwo świętokrzyskie.

\section{Wprowadzenie}

Problematyka dziedzictwa przemysłowego i jego współczesnego znaczenia była wielokrotnie przedmiotem dyskusji w literaturze. Autorzy najczęściej zajmują się dziedzictwem tradycyjnego przemysłu z punktu widzenia historii rozwoju kultury materialnej (np. Bielenin 1958; Przazga 1969; Czmuchowski 2013), jego wykorzystania jako atrakcji turystycznej, która może stymulować ruch turystyczny (np. Kaczmarska i Przybyłko 2010; Jędrysiak 2011; Kronenberg 2012), wartości kulturowo-architektonicznych (np. Szot-Radziszewska 2009; Furtak 2014). Znacznie rzadziej spotykamy opracowania, w których problem roli poprzemysłowych obiektów traktowany jest kompleksowo i obejmuje analizę znaczenia dla szeroko rozumianej gospodarki lokalnej, jak i dla świadomości społecznej.

Głównym celem niniejszego opracowania jest prezentacja dziedzictwa przemysłowego w dolinie rzeki Kamiennej i ocena jego znaczenia we współczesnym rozwoju tego obszaru. W artykule określono następujące cele szczegółowe: 
- określenie czynników rozwoju przemysłu w przeszłości,

- identyfikacja obiektów dziedzictwa przemysłowego doliny rzeki Kamiennej,

- ocena wykorzystania gospodarczego i społecznego znaczenia dziedzictwa przemysłowego w dolinie Kamiennej.

Artykuł traktuje o dziedzictwie poprzemysłowym specyficznego, z punktu widzenia historii gospodarczej Polski, obszaru jakim jest dolina rzeki Kamiennej. Obszar ten można określić mianem kolebki przemysłu na ziemiach polskich. Dolina rzeki Kamiennej, która stanowiła centralną część Staropolskiego Zagłębia Przemysłowego oraz funkcjonowała jako ważny obszar przemysłowy w Centralnym Okręgu Przemysłowym, skupia spuściznę dziedzictwa przemysłowego opartego na wielowiekowym rozwoju gospodarczym.

Zasadniczą część opracowania poświęconą możliwościom wykorzystania obiektów poprzemysłowych w obecnych uwarunkowaniach społeczno-gospodarczych, poprzedzono krótką charakterystyką etapów i czynników rozwoju działalności przemysłowej na tym terenie. W ostatniej części opracowania zaprezentowano wyniki badań ankietowych dotyczących społecznej percepcji przemysłowej przeszłości regionu i opinii na temat adaptacji obiektów poprzemysłowych do pełnienia nowych funkcji.

\section{Metody badań}

Metody badawcze zastosowane na potrzeby niniejszego artykułu można podzielić na te oparte na informacjach wtórnych (metody kameralne) - z literatury, rejestrów, map oraz pierwotne (metody terenowe) - oparte o badania ankietowe, inwentaryzację czy obserwację (Kowalczyk 2000).

Znaczną część materiału zgromadzono metodą badań terenowych, którymi objęto poszczególne gminy leżące wzdłuż biegu rzeki Kamiennej. Głównym celem badań terenowych była identyfikacja obiektów poprzemysłowych oraz określenie ich współczesnego znaczenia dla rozwoju gospodarczego, a także dla kształtowania lokalnej i regionalnej tożsamości wśród mieszkańców. Do przeprowadzenia badań posłużono się metodą inwentaryzacji i metodą wywiadu standaryzowanego opartego na pytaniach zawartych w kwestionariuszu. W socjologii badania kwestionariuszowe nazywane są badaniami ankietowymi, a sam kwestionariusz ankietą (Wejland 1992), dlatego w pracy określenia te używane są zamiennie.

W dolinie rzeki Kamiennej przeprowadzono łącznie 450 wywiadów, w tym 300 z mieszkańcami i 150 z turystami odwiedzającymi gminy nad rzeką Kamienną. Próbę osób ankietowanych dobrano w sposób losowy. Analizie poddane zostały m.in. postrzeganie atrakcyjności turystycznej regionu, znajomość historii czy wreszcie percepcja dziedzictwa przemysłowego.

W ramach prac kameralnych wykorzystano metodę historyczną polegającą na analizie treści prac o tematyce nawiązującej do historii badanego obszaru, a konkretnie: o czynnikach lokalizacji, a także o genezie i rozwoju przemysłu na 
ziemiach polskich. W celu pełniejszej prezentacji tych zagadnień odwołano się do materiałów historycznych zarówno pisanych, jak i kartograficznych.

Ponadto przeprowadzono kwerendę Rejestru Zabytków w województwach mazowieckim i świętokrzyskim oraz Gminnych Ewidencji Zabytków, a także analizę przewodników i wydawnictw promujących badany obszar.

\section{Przemysł w dolinie rzeki Kamiennej}

\subsection{Uwarunkowania rozwoju dzialalności przemysłowej}

Dolina Kamiennej położona jest w południowo-wschodniej Polsce u stóp Gór Świętokrzyskich. Oś doliny stanowi rzeka Kamienna - niewielka na tle kraju, stanowiąca drugą pod względem wielkości zlewni i długości $(151,5 \mathrm{~km})$ rzekę kielecczyzny (rys. 1). W odcinku ujściowym spadek wody jest niewielki, a rzeka przypomina rzekę nizinną. W odcinku źródłowym natomiast dolina rzeki jest wąska, a jej spadek jest charakterystyczny dla rzek górskich (Soja 2003; Biernat, Ciupa 2011). Z tego względu Kamienna odegrała olbrzymią rolę w rozwoju gospodarczym regionu świętokrzyskiego. Rzeka stała się osią Staropolskiego Zagłębia Przemysłowego, a siła spadku wód została wykorzystana do napędzania urządzeń mechanicznych. Traktowano ją także jako rzekę spławną, jednak nigdy nie udało się uregulować całego koryta (Zieliński 1965). Warto dodać, że rzeka Kamienna nie jest jedynym istotnym ciekiem $w$ tym regionie. Obszar ten charakteryzuje bardzo bogata sieć rzeczna, co stanowiło jeden z podstawowych czynników jego rozwoju w przeszłości.

Surowce doliny rzeki Kamiennej są jednymi z najbardziej zróżnicowanych w kraju, a Zagłębie Staropolskie stanowiło drugi co do wielkości, po złożach małopolskich, region rudonośny w Polsce. Rudy, zróżnicowane pod względem gatunków i zawartości żelaza, zalegały na różnych poziomach geologicznych - od dolnego dewonu po górną jurę i trzeciorzęd (Zieliński 1965). Najczęściej występującymi rudami były limonit i syderyt, zawierające do $40 \%$ żelaza, rzadziej hamatyt o zawartości żelaza do 70\%. Mimo, że warstwy rudonośne były bardzo rozproszone, eksploatację surowców ułatwiała ich dobra dostępność (Fierla 1979). Rozwój przemysłu w dolinie rzeki Kamiennej związany był również z występowaniem tutaj surowców skalnych wykorzystywanych dla przemysłu materiałów budowlanych.

Kolejnym istotnym czynnikiem rozwoju przemysłu w dolinie rzeki Kamiennej były zasoby energetyczne, których dostarczały lasy. Tereny wzdłuż rzeki Kamiennej charakteryzują się bogactwem i dużą różnorodnością skupisk leśnych. Przeplatają się tu drzewostany iglaste z liściastymi.

Poza sprzyjającymi czynnikami przyrodniczymi dla rozwoju przemysłu $\mathrm{w}$ tym regionie, istotne znaczenie, zwłaszcza w okresie intensyfikacji produkcji w XIX i XX wieku miały czynniki pozaprzyrodnicze. Wskazać tu należy przede 


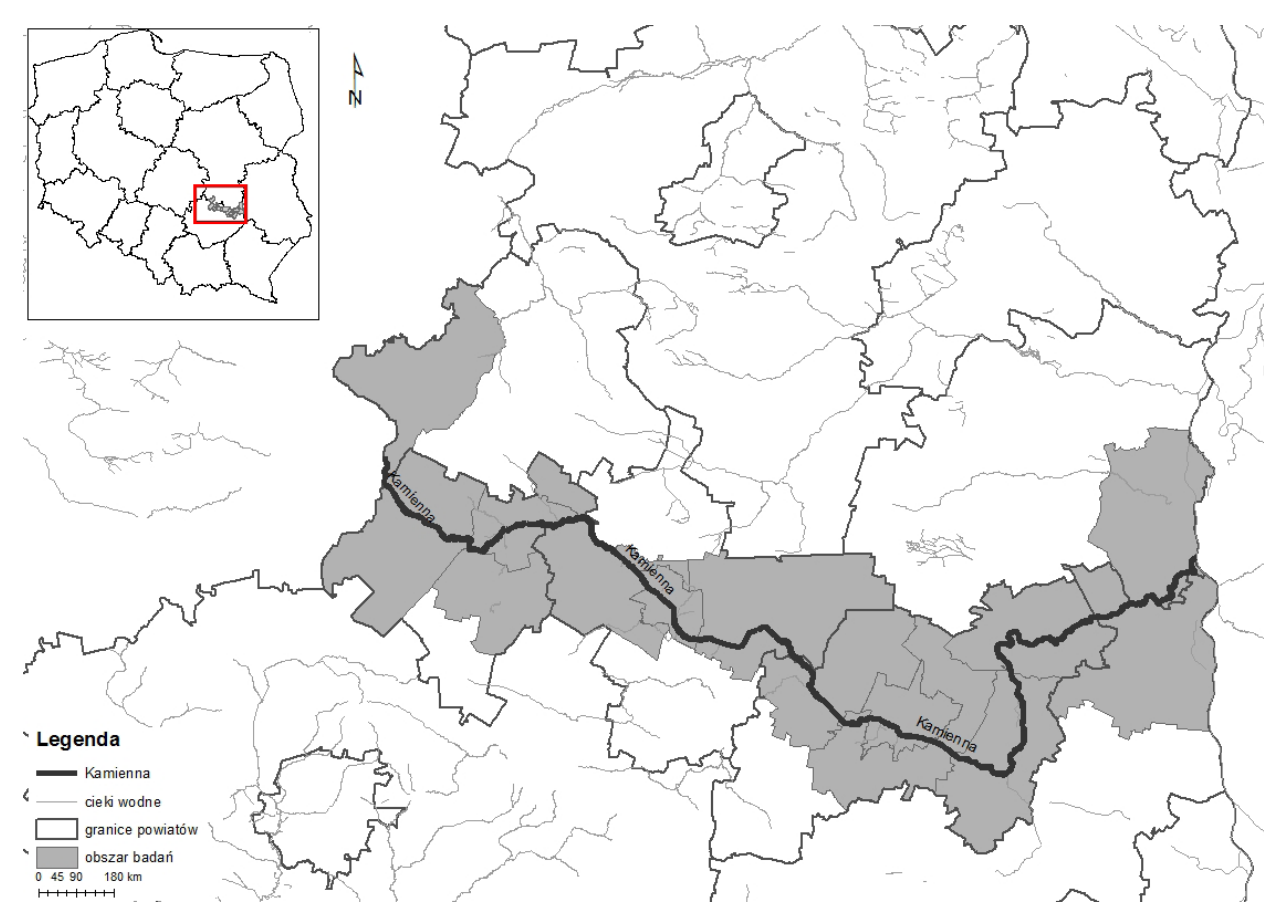

Rys. 1. Położenie rzeki Kamiennej

Źródło: opracowanie własne

wszystkim strategiczne położenie rzeki Kamiennej w tak zwanym „trójkącie bezpieczeństwa”. Rejony położone w widłach Wisły i Sanu były najbardziej oddalone od granic państwa, co stanowiło zabezpieczenie inwestycji przemysłowych na wypadek konfliktu. Dodatkowo dawały możliwość biernej obrony przeciwlotniczej dzięki dużemu zalesieniu (Bobiński 1939; Dziemianko 2007; Roszkowski 2012). Ponadto do dynamicznego rozwoju uprzemysłowienia przyczyniły się duże zasoby taniej siły roboczej w regionie (Roszkowski 2012). Kadra pracownicza nie była wysoko wykwalifikowana, jednak w początkowym okresie funkcjonowania i rozbudowy przemysłu wysokie kompetencje nie były tak istotne. Powstający przemysł stał się rozwiązaniem dla problemów demograficznych wsi na badanym obszarze. Bardzo istotnym czynnikiem wpływającym na intensyfikację przemysłu było zbudowanie w 1885 roku linii kolejowej z Dąbrowy Górniczej przez Skarżysko-Kamienną do Dęblina. Czynnik transportowy przyciągnął nad Kamienną nowe oraz zaktywizował działające już zakłady (Kamińska, Kozak 1993). Wreszcie, niemałe znaczenie dla rozwoju działalności przemysłowej nad Kamienną miało podpisanie w marcu 1928 roku rozporządzenia o ulgach dla przedsiębiorstw przemysłowych i komunikacyjnych. Poważne ulgi podatkowe przewidziane dla nowych, prywatnych inwestorów miały ożywić gospodarkę w tym regionie. 


\subsection{Rozwój działalności przemysłowej w dolinie rzeki Kamiennej}

\section{Okres przedprzemysłowy i Staropolski Okręg Przemysłowy}

Strefa doliny Kamiennej stanowiła część funkcjonującego za czasów rzymskich wielkiego okręgu produkcji żelaza, ukierunkowanego na wyspecjalizowane kopalnictwo rud. Tradycje te kontynuowano w czasach średniowiecza, a później w wieku XVIII. Wraz z unowocześnieniem technik eksploatacyjnych, rozwojem hutnictwa i wzmożonym zapotrzebowaniem na rudy żelaza w dolinie Kamiennej wzrastała liczba kopalni. Okres działalności kopalń nad Kamienną można zamknąć pomiędzy XVII a XIX wiekiem, kiedy na badanym obszarze nastąpiła aktywizacja wielkopiecownictwa (Kaptur 2014).

Po 1815 roku, kiedy powołano do istnienia Królestwo Kongresowe, a poprawę sytuacji gospodarczej w kraju upatrywano w przemyśle, Stanisław Staszic kierujący Główną Dyrekcją Górniczą w Kielcach, opracował dwuetapowy plan rozbudowy górnictwa, hutnictwa i przemysłu metalowego. Po pierwsze, zaplanowano utworzenie kombinatu fabryk żelaznych na rzece Kamiennej, po drugie, rozwój kruszcowego górnictwa i hutnictwa w okolicach Kielc (Zieliński 1965). Węzłowym punktem produkcyjnym stały się Starachowice, w których zamierzano produkować surówkę i odlewy. Celem Staszica było przeobrażenie obszaru rolniczo-leśnego w prowincję górniczą, którą zamieszkiwałaby ludność rzemieślniczo-fabryczna (Pazdur 1959). Po dymisji Staszica w 1824 roku, jego następca - Książę Ksawery Drucki-Lubecki skupił się na ukończeniu inwestycji, a także zainicjował budowę drogi wodnej na Kamiennej (Zieliński 1965).

Po upadku powstania listopadowego w 1833 roku, górnictwo i hutnictwo Zagłębia Staropolskiego przekazano pod zarząd Banku Polskiego. W kolejnych latach sprawami górnictwa i hutnictwa zajmował się Wydział Górniczy w Komisji Przychodów i Skarbu Królestwa Polskiego. W 1870 roku z rozkazu cara całkowicie wyprzedano państwowe zakłady przemysłowe, a przemysł w dolinie rzeki Kamiennej zaczął tracić na znaczeniu na rzecz ośrodków na Górnym Śląsku. W konsekwencji, pod koniec XIX wieku większość zakładów Zagłębia Staropolskiego była zacofana i przestarzała technicznie (Puś 1997).

Przygotowania do wojny na początku XX wieku stanowiły istotny impuls do rozwoju przemysłu metalowego (Zieliński 1965). Niestety, wybuch pierwszej wojny światowej w 1914 roku był tragiczny w skutkach dla zakładów leżących nad rzeką Kamienną. Zamykano zakłady, rekwirowano maszyny, produkty gotowe, surowce czy półfabrykaty. Straty poniesione podczas trwającej wojny były ogromne (Zieliński 1965).

Po odzyskaniu niepodległości w 1918 roku górnictwo i hutnictwo nad Kamienną reprezentowały zaledwie trzy zakłady przemysłowe: 1) Spółka Akcyjna Wielkich Pieców i Zakładów Ostrowieckich w Ostrowcu Świętokrzyskim, 2) Towarzystwo Starachowickich Zakładów Górniczych w Starachowicach, 3) Zakłady Górniczo-Hutnicze „Chlewiska” Sp. Akc. L.J. Borkowski. 
Pojawiła się jednak idea „trójkąta bezpieczeństwa”, do której centralne położenie na tle kraju oraz baza lokalnych surowców mineralnych sytuowały dolinę Kamiennej na preferencyjnej pozycji (Zieliński 1965).

\section{Funkcjonowanie doliny Kamiennej w COP}

Idea Centralnego Okręgu Przemysłowego pojawiła się w 1928 roku. Okręg miał za zadanie stworzenie podstaw dla industrializacji kraju oraz unormowanie nadwyżki siły roboczej, a przede wszystkim zabezpieczenie kraju na wypadek agresji ze strony Hitlera (Zieliński 1965). Obszar podzielono na trzy mniejsze regiony o odmiennym charakterze (rys. 2). Były to: kielecki region surowcowy (A), w którym znalazła się bogata w surowce mineralne dolina rzeki Kamiennej, lubelski region aprowizacyjny (B) oraz sandomierski region przemysłowo-przetwórczy (C) (Bobiński 1939; Zieliński 1965; Orłowski 2007). Przemysł doliny Kamiennej w okresie funkcjonowania Centralnego Okręgu Przemysłowego stanowiły zasadniczo dwa zakłady położone w centrum „trójkąta bezpieczeństwa” - Ostrowickie i Starachowickie.

\section{Legenda}
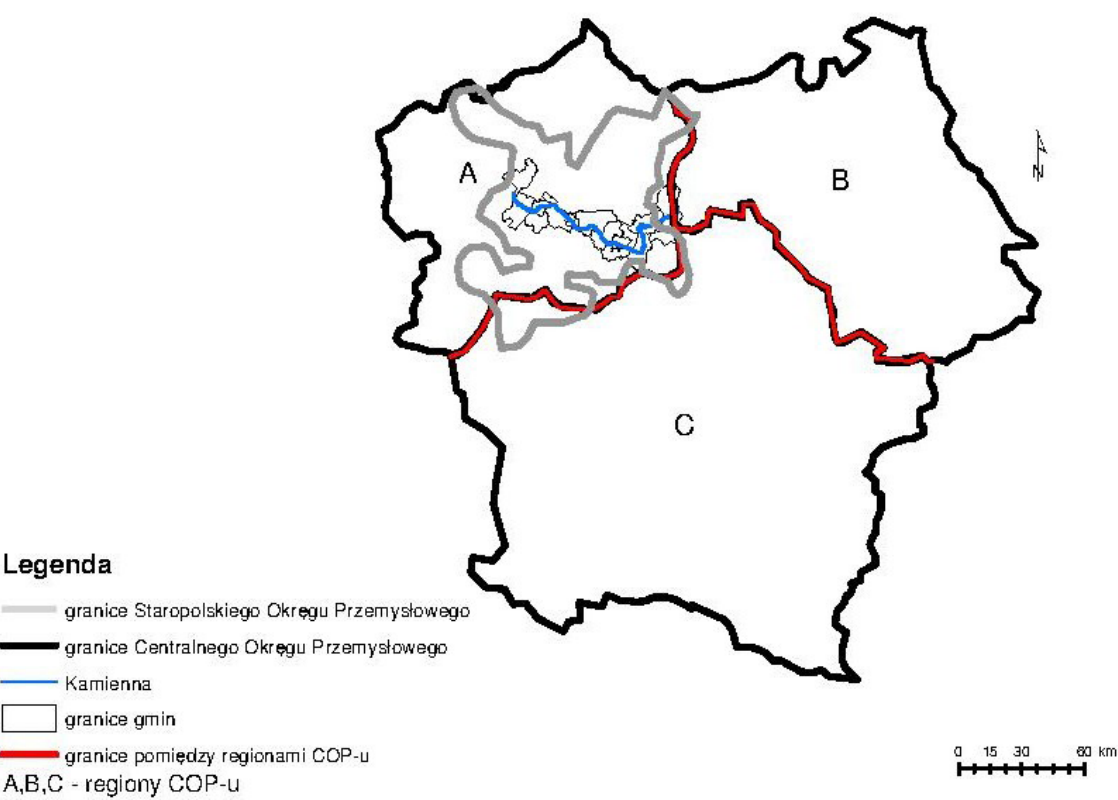

Rys. 2. Położenie obszaru badań w granicach Staropolskiego

i Centralnego Okręgu Przemysłowego

Źródło: opracowanie własne na podstawie: S. Bobiński (1939) 
Rozwój przemysłu doliny Kamiennej w Centralnym Okręgu Przemysłowym podupadł wraz ze wzrostem nastroju wojennego. W czasie II wojny światowej zginęło około 30\% ludności żyjącej i pracującej w dolinie Kamiennej. Podczas okupacji Niemcy zalali czynne kopalnie rud żelaza, zniszczono żelazne i żelbetonowe mosty na rzece Kamiennej. Ocalały jedynie zakłady metalowe w Starachowicach, Chlewiskach oraz inne mniejsze zakłady.

\section{Okres powojenny}

W 1945 roku ruszył program odbudowy przemysłu. Podjęto m.in. próbę odbudowy huty w Ostrowcu Świętokrzyskim, co było najtrudniejsze ze względu na ogromne straty urządzeń i maszyn, które Niemcy wywieźli w trakcie wojny do Rzeszy. Zakłady w Starachowicach rozszerzyły profil swojej działalności, przekształcając się z zakładów zbrojeniowych w pierwszą w Polsce Ludowej Fabrykę Samochodów Ciężarowych, a w Skarżysku-Kamiennej odbudowano Zakłady Metalowe i Odlewnię wraz z Emaliernią. W latach 1947-1949 przystąpiły do pracy Zakłady Porcelany w Ćmielowie, Fabryka Tektury i Papieru w Bodzentynie oraz Fabryka Maszyn Rolniczych w Kunowie (Zieliński 1965).

W latach 1950-1960 realizowano kolejne plany gospodarcze, które pomimo założeń równomiernego rozwoju kraju, koncentrowały się na najbardziej uprzemysłowionej części Zagłębia - dolinie rzeki Kamiennej pogłębiając istniejące już wcześniej dysproporcje w tym regionie (Zieliński 1965). Na terenie Zagłębia nastąpiła koncentracja zakładów przemysłu środków transportu, hutnictwa żelaza, przemysłu maszynowego i metalowego oraz przemysłu materiałów budowlanych. Pozostałe gałęzie przemysłu miały niski udział w produkcji ogólnej (rys. 3).

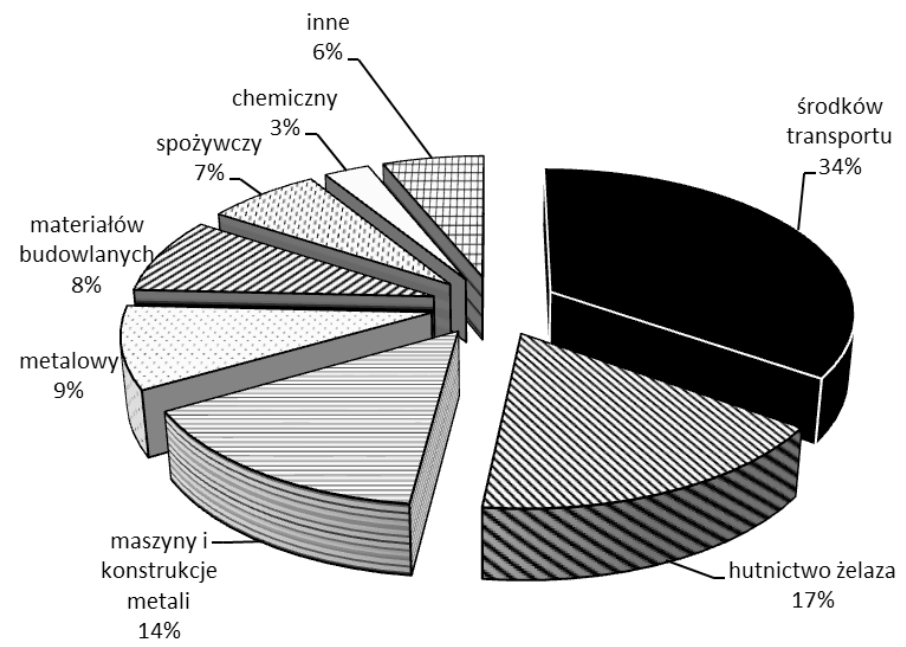

Rys. 3. Udział głównych gałęzi przemysłu w Okręgu Staropolskim w 1968 roku Źródło: opracowanie własne na podstawie: S. Przazga (1969) 
W latach 60. i 70. XX wieku zaprzestano niemal całkowicie eksploatacji surowców metalicznych. W okresie transformacji ustrojowej większość zakładów została sprywatyzowana, a kapitał przejęli zagraniczni inwestorzy. Współcześnie w dolinie rzeki Kamiennej przemysł nie ma większego znaczenia, rozwijają się natomiast usługi i branża turystyczna.

\section{Materialne dziedzictwo przemysłowe we współczesnej strukturze gospodarczej}

\subsection{Obiekty (po)przemyslowe}

\section{Działalność górnicza}

Ślady dawnej działalności górniczej obecne są po obu stronach rzeki Kamiennej. Górny i środkowy odcinek biegu rzeki charakteryzuje się jednak dużo większą koncentracją dawnych wyrobisk kopalnianych niż odcinek dolny, w którym wydobycie rud żelaza było znikome (rys. 4).

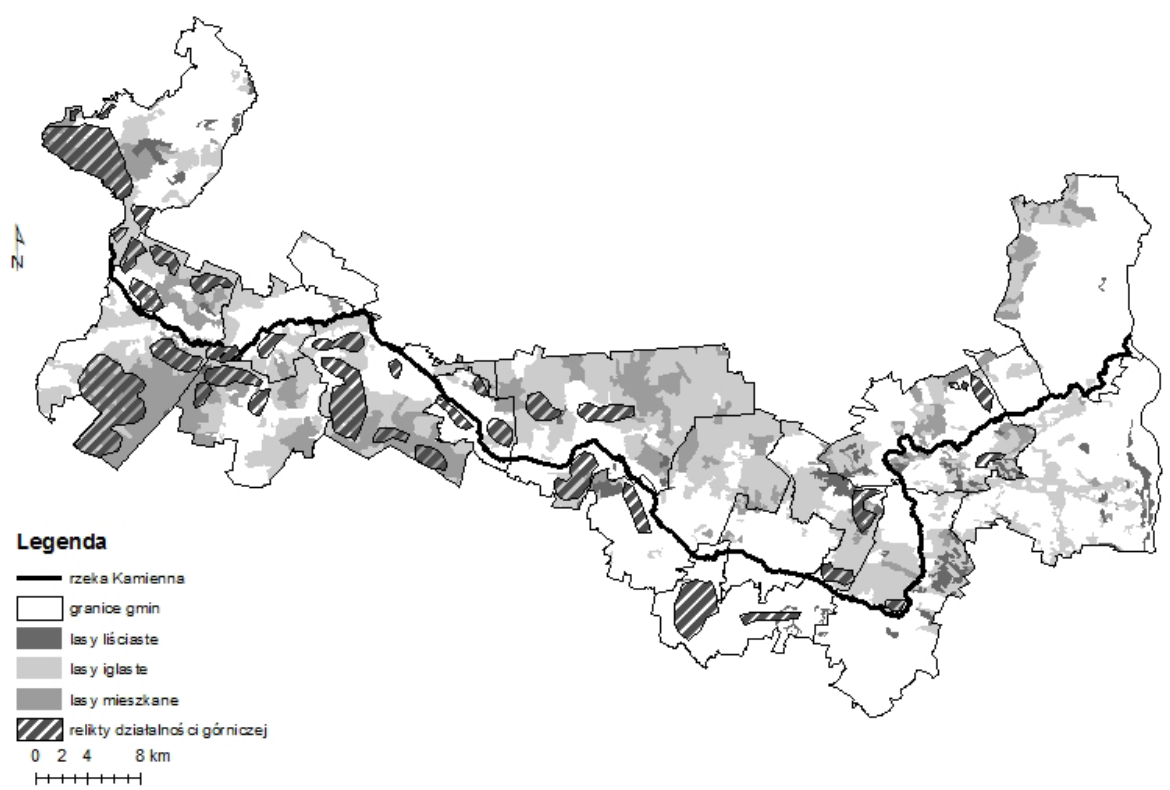

Rys. 4. Rozmieszczenie reliktów kopalń rud żelaza w dolinie rzeki Kamiennej Źródło: opracowanie własne na podstawie podkładu Cieniowanie ISOK

\section{Przemysł metalurgiczny}

Niewątpliwie do najważniejszych zabytków związanych z przemysłem metalurgicznym w dolinie Kamiennej należą zakłady wielkopiecowe, które stanowiły starannie zaplanowane założenia obejmujące budynki zakładowe, budynki 
przyfabryczne, pełniące funkcję administracyjną, a często także osiedla robotnicze. Zakłady wielkopiecowe działające w oparciu o wielki piec, który zastąpił w XVIII wieku dymarki istniały m.in. w Parszowie, Mostkach, Skarżysku-Kamiennej, Ostrowcu czy Starachowicach. Produkowano w nich głównie surówkę i odlewy: blachy, kotły, piece itp. W XIX wieku przy zakładach wybudowano osiedla fabryczne dla pracowników i ich rodzin.

Współcześnie największym kombinatem metalurgicznym nad rzeką Kamienną jest Huta Ostrowiec będąca własnością hiszpańskiej grupy Celsa. Zakład wykorzystuje budynki stanowiące materialne dziedzictwo przemysłowe doliny Kamiennej. Inne założenia hutnicze są zatarte. W przestrzeni widoczne są nieliczne budynki lub fundamenty działających zakładów i wielkich pieców. W krajobrazie łatwo dostrzegalne są pozostałości ujęć wody wykorzystywanej w procesie produkcyjnym: groble ziemne, przepusty, kanały czy zbiorniki wodne oraz żużle wielkopiecowe.

\section{Przemysł zbrojeniowy}

W dolinie rzeki Kamiennej funkcjonowały dwie duże inwestycje o charakterze zbrojeniowym - Zakład Hutniczo-Metalurgiczny w Starachowicach oraz największa fabryka amunicji, która powstała w Skarżysku-Kamiennej. Lokalizacja zakładów zbrojeniowych miała szereg uzasadnień, po pierwsze decydowały względy bezpieczeństwa, po drugie dogodne położenie komunikacyjne w krzyżu przemysłowym (Krauze 2012).

Współcześnie Państwowa Fabryka Amunicji działająca pod nazwą MESKO Spółka Akcyjna, będąca częścią koncernu Polska Grupa Zbrojeniowa wykorzystuje zabudowę fabryczną z lat 20. XX wieku. Funkcjonująca fabryka rozwinęła także swój pierwotny profil i produkuje obecnie również urządzenia gospodarstwa domowego i maszyny rolnicze.

\section{Przemysł mineralny}

Potężny rozwój przemysłu mineralnego nad Kamienną zapoczątkował Stanisław Staszic, który budował cegielnie i wapienniki w pobliżu już istniejących, dużych inwestycji przemysłowych. Szybkie tempo rozwoju gospodarczego, potrzeby budownictwa mieszkalnego i socjalnego oraz znaczne zasoby surowców mineralnych stanowiły główne przesłanki do rozwoju przemysłu mineralnego w dolinie rzeki Kamiennej (Zieliński 1965).

Dolina rzeki Kamiennej zasłynęła także jako ważny ośrodek kamieniarstwa i ceramiki. Współcześnie w dolinie Kamiennej kontynuowane jest wydobycie surowców skalnych przeznaczonych na materiały budowlane oraz glinek wykorzystywanych do produkcji porcelany. Przemysł wyrobów z surowców niemetalicznych systematycznie się rozwija, a jego pozostałości można łatwo zauważyć w przestrzeni w formie poeksploatacyjnych ścian skalnych kamieniołomów i wapienników. 


\subsection{Obiekty towarzyszące}

\section{Budownictwo hydrotechniczne}

W dolinie rzeki Kamiennej już w XVI wieku istniało 27 obiektów wodno-energetycznych. W zakładach usytuowanych na brzegu rzeki pracowały koła wykorzystujące wody przepływowe. Budowano także układy kanałów i zbiorniki wodne, a także spiętrzano wodę jazami budowanymi w poprzek koryta rzecznego (Balińska 1999). Ślady dawnych budowli wodnych zachowały się jedynie w formie pozostałości dawnych zapór ziemnych. Rzeka Kamienna miała pełnić nie tylko rolę źródła energii do procesów produkcyjnych, ale także drogi wodnej umożliwiającej transport wyrobów pomiędzy zakładami oraz do innych miast. W latach 20. XIX wieku rozpoczęto oczyszczanie nadbrzeża i koryta Kamiennej oraz jej regulację (Zieliński 1965). W rezultacie w dolinie rzeki Kamiennej powstało interesujące świadectwo myśli technologicznej stanowiące dziedzictwo przemysłowe badanego obszaru.

Pozostałości dawnych układów hydroenergetycznych można dostrzec nad rzeką Kamienną współcześnie (fot. 1). Zachowały się fragmenty układów wodnych w Skarżysku-Kamiennej (Bzin), Marcinkowie, Nietulisku i Parszowie. Mimo, że zbiorniki wodne zostały zasypane lub wkracza na nie zabudowa, kanały robocze są nadal czytelne w poprzemysłowej przestrzeni. Na rzece Kamiennej istnieją współcześnie cztery zbiorniki wodne: w Bliżynie, Wąchocku, Starachowicach i Brodach. Są to zbiorniki sztuczne, wykorzystywane w przeszłości do celów przemysłowych. Zachowane elementy hydrotechniczne zagospodarowano pod współcześnie zmodernizowane zalewy, funkcjonujące głównie jako zbiorniki rekreacyjne i retencyjne.

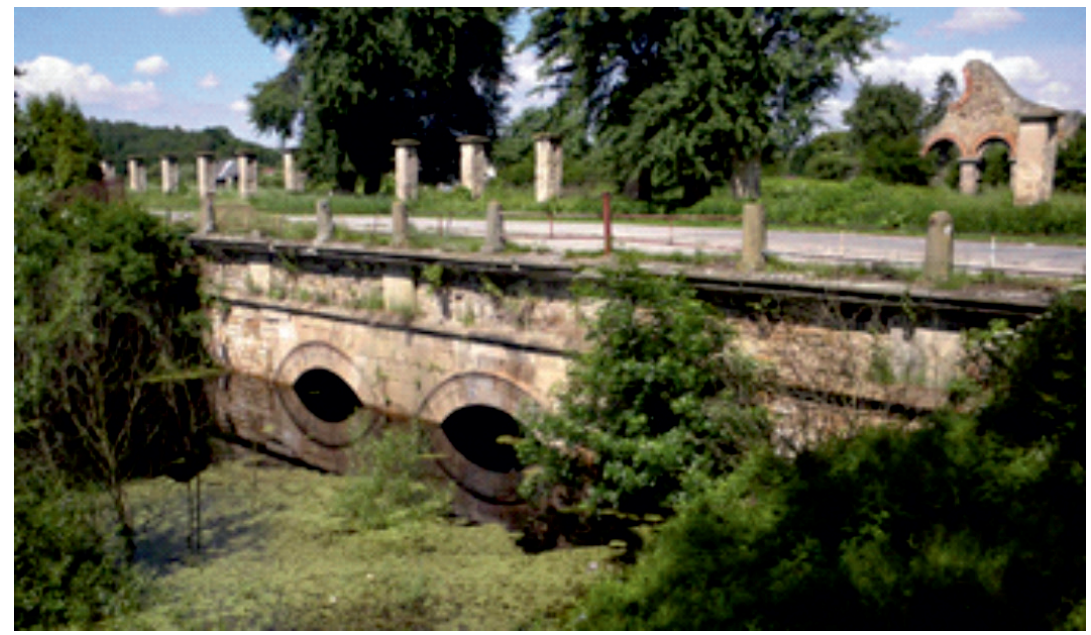

Fot. 1. Most na kanale kunowskim w Nietulisku Dużym Źródło: http://ostrowiec.travel/pl (dostęp: 10.05.2015) 


\section{Osiedla dla pracowników}

Wraz z rozwojem przemysłu, w dolinie rzeki Kamiennej, a co za tym idzie z rozbudową fabryk, zakładów przemysłowych i hut, wzrastało zapotrzebowanie na mieszkania dla robotników i urzędników. W efekcie, w otoczeniu zakładów przemysłowych powstawały osiedla mieszkaniowe urozmaicające krajobraz miast położonych w dolinie rzeki Kamiennej (Furtak 2014). Osiedla robotnicze w Skarżysku-Kamiennej, Ostrowcu Świętokrzyskim, Starachowicach czy innych, mniejszych ośrodkach badanego obszaru stanowią interesującą spuściznę dziedzictwa przemysłowego. Powstawały one w różnych okresach, począwszy od drugiej połowy XIX wieku. W okresie funkcjonowania Centralnego Okręgu Przemysłowego nowe osiedla nawiązywały do idei miast-ogrodów, były wyposażone w najnowocześniejszą infrastrukturę społeczną i techniczną. Jedną z pierwszych w XX wieku kolonii fabrykanckich była Kolonia Robotnicza położona na północny zachód od Ostrowca Świętokrzyskiego. Jej śladem jest kilka parterowych domów, które niestety są przebudowywane i stopniowo ulegają degradacji (fot. 2-3).
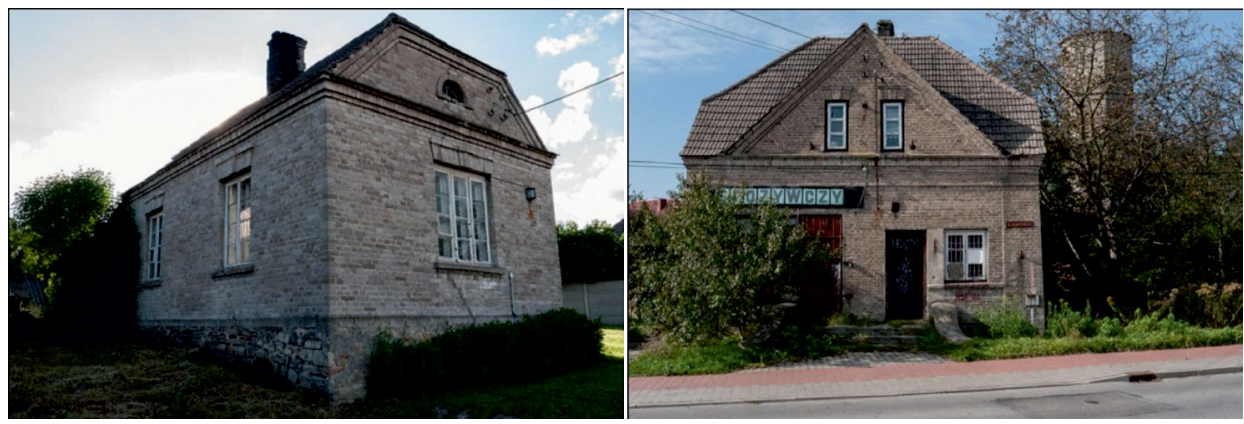

Fot. 2-3. Pozostałości Kolonii Robotniczej w Ostrowcu Świętokrzyskim Źródło: http://koloniarobotnicza.wix.com (dostęp: 10.05.2015)

\section{Współczesne znaczenie społeczno-gospodarcze dziedzictwa przemysłowego}

\subsection{Wykorzystanie obiektów poprzemysłowych}

Na podstawie inwentaryzacji terenowej dokonano analizy współczesnego wykorzystania 72 dawnych obiektów przemysłowych w dolinie rzeki Kamiennej, których wykaz umieszczono $\mathrm{w}$ poniższej tabeli 1 . Najważniejszym trendem $\mathrm{w}$ ich zagospodarowaniu jest tworzenie muzeów i skansenów przemysłowych.

Obiekty muzealne powstały $\mathrm{w}$ dawnych zakładach przemysłowych lub w budynkach administracji i zarządu tychże zakładów. Relikty działalności Staropolskiego, a później Centralnego Okręgu Przemysłowego prezentowane są w sposób wystawienniczy dla zainteresowanych produkcją przemysłową, jej 
procesem i efektami. Pokazy oparte są na użytkowaniu zgodnym z pierwotnym i polegają na okazjonalnym uruchomieniu maszyn i urządzeń. Drugim istotnym trendem jest umożliwianie zwiedzania obiektów w ich obecnym stanie oraz wykorzystywanie do aktywnych form spędzania czasu. Wprowadzenie funkcji turystycznej do zabytków industrialnych w dolinie rzeki Kamiennej z jednej strony zapoznaje turystę z procesem technologicznym i dawną architekturą, z drugiej zaś pozwala zachować przemysłowy charakter obszaru (Molenda 2010).

Tabela 1

Obiekty muzealne w dolinie rzeki Kamiennej

\begin{tabular}{|c|c|c|c|c|}
\hline Obiekt & $\begin{array}{c}\text { Części } \\
\text { składowe }\end{array}$ & $\begin{array}{l}\text { Obecna } \\
\text { funkcja }\end{array}$ & $\begin{array}{c}\text { Rok } \\
\text { udostępnienia }\end{array}$ & Adres \\
\hline $\begin{array}{l}\text { Zabytkowa Huta } \\
\text { Żelaza }\end{array}$ & $\begin{array}{l}\text { zakład } \\
\text { wielkopiecowy }\end{array}$ & $\begin{array}{l}\text { Muzeum Hutnictwa } \\
\text { i Przemysłu } \\
\text { Maszynowego }\end{array}$ & 1960 & Chlewiska \\
\hline $\begin{array}{l}\text { Zakłady } \\
\text { Wielkopiecowe } \\
\text { w Rejowie }\end{array}$ & $\begin{array}{l}\text { budynek } \\
\text { zawiadowcy } \\
\text { huty }\end{array}$ & $\begin{array}{l}\text { Muzeum im. „Orła } \\
\text { Białego” }\end{array}$ & 1969 & $\begin{array}{l}\text { Skarżysko- } \\
\text {-Kamienna }\end{array}$ \\
\hline $\begin{array}{l}\text { Starachowickie } \\
\text { Zakłady } \\
\text { Górniczo- } \\
\text {-Hutnicze }\end{array}$ & $\begin{array}{l}\text { budynek } \\
\text { dozorstwa } \\
\text { wielkich pieców }\end{array}$ & $\begin{array}{l}\text { Muzeum } \\
\text { Regionalne PTTK }\end{array}$ & 1973 & Starachowice \\
\hline $\begin{array}{l}\text { Kompleks } \\
\text { prahistorycznych } \\
\text { kopalń krzemie- } \\
\text { nia pasiastego } \\
\text { w Krzemionkach } \\
\text { koło Ostrowca } \\
\text { Świętokrzyskiego }\end{array}$ & $\begin{array}{l}\text { podziemne } \\
\text { kopalnie } \\
\text { krzemienia }\end{array}$ & $\begin{array}{l}\text { Muzeum } \\
\text { Archeologiczne } \\
\text { i Rezerwat } \\
\text { „Krzemionki” }\end{array}$ & 1979 & Krzemionki \\
\hline $\begin{array}{l}\text { Młyn wodny } \\
\text { południowy na } \\
\text { rzece Kamiennej }\end{array}$ & młyn wodny & $\begin{array}{l}\text { galeria sztuki } \\
\text { i żywe muzeum } \\
\text { Stary Młyn }\end{array}$ & 2001 & Bałtów \\
\hline $\begin{array}{l}\text { Zakład } \\
\text { Wielkopiecowy } \\
\text { w Starachowicach }\end{array}$ & $\begin{array}{l}\text { budynki } \\
\text { fabryczne }\end{array}$ & $\begin{array}{l}\text { Muzeum Przyrody } \\
\text { i Techniki } \\
\text { Ekomuzeum } \\
\text { im. Jana Pazdura } \\
\text { w Starachowicach }\end{array}$ & 2001 & Starachowice \\
\hline $\begin{array}{l}\text { Fabryka } \\
\text { Porcelany } \\
\text { AS Ćmielów }\end{array}$ & $\begin{array}{l}\text { hala fabryczna } \\
\text { i piec garncarski }\end{array}$ & $\begin{array}{l}\text { Żywe Muzeum } \\
\text { Porcelany }\end{array}$ & 2005 & Ćmielów \\
\hline
\end{tabular}

Źródło: opracowanie własne. 
Ruch turystyczny we wskazanych obiektach dziedzictwa przemysłowego jest trudno mierzalny z uwagi na różny sposób rejestracji turystów. Część obiektów rejestruje gości poprzez sprzedaż biletów, w niektórych dane te są szacunkowe i określone przez dyrekcję, a w jeszcze innych w ogóle nie prowadzi się rejestracji. Sytuacja ta stanowi utrudnienie w porównywaniu danych w poszczególnych obiektach (tab. 2).

Tabela 2

Ruch turystyczny w muzeach w dolinie rzeki Kamiennej

\begin{tabular}{|c|c|c|c|c|}
\hline \multirow{2}{*}{ Nazwa muzeum } & \multirow{2}{*}{$\begin{array}{c}\text { Rok } \\
\text { udostępnienia }\end{array}$} & \multirow{2}{*}{ Lokalizacja } & \multicolumn{2}{|c|}{ Ruch turystyczny } \\
\hline & & & 2008 & 2014 \\
\hline $\begin{array}{l}\text { Muzeum } \\
\text { Hutnictwa } \\
\text { i Przemysłu } \\
\text { Maszynowego }\end{array}$ & 1960 & Chlewiska & 3958 & 5937 \\
\hline $\begin{array}{l}\text { Muzeum } \\
\text { im. „Orła Białego” }\end{array}$ & 1969 & $\begin{array}{l}\text { Skarżysko- } \\
\text {-Kamienna }\end{array}$ & 19980 & 25609 \\
\hline $\begin{array}{l}\text { Muzeum } \\
\text { Regionalne PTTK }\end{array}$ & 1973 & Starachowice & \multicolumn{2}{|c|}{ brak danych } \\
\hline $\begin{array}{l}\text { Muzeum } \\
\text { Archeologiczne } \\
\text { i Rezerwat } \\
\text { „Krzemionki” }\end{array}$ & 1979 & Krzemionki & 52231 & 35406 \\
\hline $\begin{array}{l}\text { Galeria sztuki } \\
\text { i żywe muzeum } \\
\text { Stary Młyn }\end{array}$ & 2001 & Bałtów & \multicolumn{2}{|c|}{$\begin{array}{l}\text { ruch turystyczny nie jest } \\
\text { rejestrowany }\end{array}$} \\
\hline $\begin{array}{l}\text { Muzeum } \\
\text { Przyrody } \\
\text { i Techniki } \\
\text { Ekomuzeum } \\
\text { im. Jana Pazdura } \\
\text { w Starachowicach }\end{array}$ & 2001 & Starachowice & 13487 & 19409 \\
\hline $\begin{array}{l}\text { Żywe Muzeum } \\
\text { Porcelany }\end{array}$ & 2005 & Ćmielów & 16000 & 17000 \\
\hline
\end{tabular}

Źródło: opracowanie własne na podstawie danych uzyskanych w muzeach.

W rozkładzie ruchu turystycznego wyraźnie zaznacza się sezonowość. Najwięcej turystów odwiedza analizowane obiekty w miesiącach letnich w okresie wakacji. W przypadku pozostałych miesięcy muzea odwiedzają przede wszystkim mieszkańcy badanego obszaru i sąsiednich gmin, ruch turystyczny jest w nich niewielki. 
Dziedzictwo industrialne doliny rzeki Kamiennej stanowi niewątpliwie oryginalny produkt turystyczny. Wielkość ruchu turystycznego w badanych obiektach wskazuje, że cieszą się one dość dużym zainteresowaniem zwiedzających, których przyciąga unikatowa, zabytkowa architektura przemysłowa. Obiekty poprzemysłowe, chociaż cieszą się zainteresowaniem turystów, to jednak nie do końca wykorzystują swój potencjał. Dlatego zainteresowanie zabytkami Staropolskiego Okręgu Przemysłowego jest dużo mniejsze niż na przykład Szlakiem Zabytków Techniki Województwa Śląskiego (Molenda 2010). Tylko niektóre z funkcjonujących tutaj obiektów organizują wydarzenia kulturalne, pokazy czy wystawy czasowe mające przyciągnąc turystów. Ponadto turystyka industrialna nad rzeką Kamienną musi się zmierzyć z brakiem infrastruktury pobytowej (noclegi, usługi gastronomiczne) zapewniającej całościową obsługę turystów.

Pofabryczną przestrzeń w dolinie rzeki Kamiennej, poza obiektami muzealnymi, zaadaptowano na inne cele oświatowo-wychowawcze oraz społeczno-kulturalne. Towarzyszące dawnym obiektom produkcyjnym zespoły domów robotniczych, które zaadoptowano na mieszkania prywatne, nadal pełnią swoje pierwotne funkcje. Proces prywatyzacji jakiemu uległa mieszkalna zabudowa poprzemysłowa spowodował jednak niekontrolowane zmiany w fizjonomii budynków. Przebudowa ich bryły, ukrycie zabytkowych elewacji pod systemem dociepleń, zmiana kolorystyki czy modyfikacja kształtu i pokrycia dachu skutkują sukcesywnym zacieraniem charakterystycznych elementów ich konstrukcji.

\section{Znaczenie społeczne dziedzictwa przemysłowego w dolinie Kamiennej}

\subsection{Dziedzictwo przemyslowe w percepcji mieszkańców}

Celem badania ankietowego przeprowadzonego wśród mieszkańców gmin leżących w dolinie rzeki Kamiennej było poznanie ich opinii na temat regionu, w którym żyją, a w szczególności znaczenia dziedzictwa przemysłowego oraz znajomości historii regionu. W prowadzonym badaniu wzięło udział 300 osób.

W opinii większości ankietowanych szczególnym atutem regionu jest jego przemysłowa przeszłość i zachowane elementy przemysłowego dziedzictwa. Uregulowana rzeka Kamienna, wybudowane na niej zbiorniki wodne, fabryki oraz inne elementy kojarzące się z Zagłębiem Przemysłowym, w tym również muzea, które zachowują pamięć o historii doliny Kamiennej są niewątpliwie ważną częścią badanej przestrzeni. Dlatego według $67 \%$ badanych to właśnie dziedzictwo przemysłowe (historia i zabytki) doliny rzeki Kamiennej powinno stanowić główny element promocji regionu.

Niestety, tylko niewiele ponad połowa badanych potrafiła wskazać cykliczne wydawnictwo płatne lub bezpłatne promujące i informujące o wydarzeniach kulturalnych w regionie. Wskazywano głównie takie źródła, jak: Informator Turystyczny Województwa Świętokrzyskiego (49\%), lokalna prasa (24\%) oraz 
materiały dostępne na stronach internetowych województw, powiatów i gmin (23\%). Większość respondentów (niemalże 80\%) zna atrakcyjne wydarzenia muzyczne, festyny czy święta związane z regionem. Jednak tylko 55\% badanych uczestniczyło kiedykolwiek w tego typu imprezach. Najbardziej znanym świętem wśród respondentów okazały się Dymarki Świętokrzyskie organizowane w Nowej Słupi (49\%), Wytopki Ołowiu w Tokarni (22\%), Święto Żelaza i Stali w Chlewiskach (13\%) oraz Turniej Sołtysów w Wąchocku (9\%). Wydarzenia te ściśle związane są z promowaniem dziedzictwa przemysłowego i turystyki industrialnej w dolinie rzeki Kamiennej. Oferta wydarzeń kulturalnych systematycznie organizowanych w regionie jest jednak dużo szersza (tab. 3).

Tabela 3

Oferta wydarzeń kulturalnych w dolinie rzeki Kamiennej

\begin{tabular}{|c|c|c|c|}
\hline Nazwa & Miejscowość & Data & Opis \\
\hline $\begin{array}{l}\text { Dymarki } \\
\text { Świętokrzyskie }\end{array}$ & Nowa Słupia & sierpień & $\begin{array}{l}\text { pokazy wytopu rudy żelaza } \\
\text { w piecach dymarskich oparte } \\
\text { na komentarzu naukowym }\end{array}$ \\
\hline Wytopki Ołowiu & Tokarnia & czerwiec & $\begin{array}{l}\text { pokazy wytopu ołowiu trady- } \\
\text { cyjną metodą; } \\
\text { występy prezentujące folklor } \\
\text { i sztukę ludową }\end{array}$ \\
\hline $\begin{array}{l}\text { Piknik } \\
\text { Gombrowiczowski }\end{array}$ & $\begin{array}{l}\text { Doły Biskupie, } \\
\text { Ostrowiec } \\
\text { Świętokrzyski, } \\
\text { Bodzechów }\end{array}$ & czerwiec-lipiec & $\begin{array}{l}\text { plenerowa impreza poświę- } \\
\text { cona postaci i twórczości } \\
\text { Witolda Gombrowicza }\end{array}$ \\
\hline \begin{tabular}{l|} 
Festyn \\
Technologiczno- \\
-Turystyczny \\
„Kuźnice Koneckie”
\end{tabular} & $\begin{array}{l}\text { Sielpia, } \\
\text { Stara Kuźnica, } \\
\text { Maleniec }\end{array}$ & lipiec & $\begin{array}{l}\text { festyn, podczas którego } \\
\text { w zabytkach techniki prezen- } \\
\text { towane są działania urządzeń } \\
\text { przemysłowych SOP-u }\end{array}$ \\
\hline Żelazne Korzenie & Starachowice & maj & $\begin{array}{l}\text { pokazy i warsztaty archeolo- } \\
\text { giczne z udziałem młodzieży } \\
\text { i osób dorosłych }\end{array}$ \\
\hline Jarmark u Strzecha & Starachowice & maj & $\begin{array}{l}\text { impreza w Muzeum Przyrody } \\
\text { i Techniki im. J. Pazdura, } \\
\text { zwiedzanie i poznanie funk- } \\
\text { cjonowania zabytków techniki }\end{array}$ \\
\hline $\begin{array}{l}\text { Święto Żelaza } \\
\text { i Stali }\end{array}$ & Chlewiska & sierpień & $\begin{array}{l}\text { festyn, podczas którego zoba- } \\
\text { czyć można Hutę Żelaza i eks- } \\
\text { pozycje muzealne, w programie } \\
\text { również występy ludowe }\end{array}$ \\
\hline
\end{tabular}

Źródło: opracowanie własne. 
Zdaniem większości respondentów, obszar położony w dolinie rzeki Kamiennej uchodzi za bardzo atrakcyjny pod względem możliwości rozwoju turystyki, o czym świadczy fakt, że respondenci pytani o jego współczesne funkcje zdecydowanie najczęściej (71\%) mówili o turystyce. Obok cech pozytywnych respondenci wskazywali również na słabości regionu - głównie niszczejące zabytki i bezrobocie. Zdaniem większości ankietowanych, turystyczną atrakcyjność regionu znacząco obniżają: niedobór programów zagospodarowania atrakcyjnych turystycznie obiektów, zły stan techniczny zabytków oraz słaba baza turystyczna.

\subsection{Znaczenie dziedzictwa przemysłowego regionu dla turystów}

Celem badania ankietowego wśród turystów odwiedzających dolinę rzeki Kamiennej było poznanie ich opinii o regionie i jego największych atrakcjach. W przeprowadzonym badaniu ankietowym wzięło udział 150 respondentów.

W strukturze ruchu turystycznego $\mathrm{w}$ obrębie badanych gmin dominują odwiedziny krótkookresowe (1-3 dni), na które przypada prawie $2 / 3$ przyjazdów, podczas gdy długookresowe (4 dni i dłużej) stanowią zaledwie $35 \%$ wszystkich przyjazdów. Wśród motywów przyjazdów krótkookresowych w okolicę rzeki Kamiennej przeważały wizyty u krewnych i/lub znajomych (21\%), choć równie często respondenci wymieniali: zwiedzanie zabytków architektury (19\%), uczestnictwo w wydarzeniach kulturalnych w regionie (18\%), czy uprawianie sportu (9\%). Wśród motywów, jakimi kierowali się turyści wybierający dłuższy pobyt w dolinie rzeki Kamiennej zdecydowanie przeważał natomiast odpoczynek na łonie natury (34\%). Ankietowani turyści kierowali się także, podobnie jak w przypadku wyjazdów krótkookresowych, chęcią odwiedzenia rodziny i znajomych (19\%). W następnej kolejności pojawiały się: uprawianie sportu i wydarzenia kulturowe w regionie. Ciekawym jest, że zwiedzaniem zabytków architektury w dolinie Kamiennej w czasie trwającego 4 i więcej dni pobycie, zainteresowanych było zaledwie $8 \%$ respondentów. Przyjazdy nad rzekę Kamienną mają w większości charakter indywidualny lub rodzinny (42,6\%), a najczęściej wybieranym środkiem komunikacji jest własny samochód (60\% odpowiedzi). Kolejnym wskazywanym środkiem transportu wybieranym przez turystów jest pociąg $(23 \%)$ oraz autokar turystyczny $(10 \%)$. Mimo, że obszar badań znalazł się poza europejską siecią korytarzy transportowych (TEN-T), która tworzona jest przez projektowane autostrady i główne linie kolejowe, dostępność komunikacyjną regionu oceniano bardzo dobrze $(38,7 \%)$.

Atrakcje w dolinie rzeki Kamiennej dobrze i bardzo dobrze oceniło $78 \%$ ankietowanych. Co ciekawe, ze względu na walory środowiska przyrodniczego i urzekające krajobrazy tego terenu, głównym skojarzeniem z doliną rzeki Kamiennej stały się dla ankietowanych Góry Świętokrzyskie (78\% respondentów), a o atrakcyjności regionu decydują, zdaniem ankietowanych turystów, głównie ciekawa 
rzeźba terenu - aż $72 \%$ i kompleksy leśne - 43\%. Szeroka oferta szlaków rowerowych i pieszych jest wyznacznikiem atrakcyjności dla 95\% badanych. Na możliwość wypoczynku w spokojnej okolicy o niskim stopniu zurbanizowania zwracało natomiast uwagę $1 / 3$ pytanych. Mimo, że Kamienna wraz z doskonale zachowanymi zabytkami techniki zabiera turystów w swoistą podróż po Staropolskim Zagłębiu Przemysłowym, to zaledwie 15\% ankietowanych właśnie z dawnym przemysłem kojarzy ten obszar. Poznawaniem dziedzictwa przemysłowego nad rzeką Kamienną zainteresowanych jest tylko 40\% pytanych, a jedynie 3\% uważa zabytki architektury przemysłowej za główną atrakcję turystyczną regionu.

\section{Podsumowanie}

W artykule podjęto próbę kompleksowej charakterystyki dziedzictwa przemysłowego w dolinie rzeki Kamiennej - od uwarunkowań dla rozwoju przemysłu, przez jego historię aż po ślady pozostawione w przestrzeni oraz ich znaczenie dla mieszkańców i turystów.

Na badanym odcinku doliny rzeki stwierdzono obecność 72 obiektów dawnej zabudowy przemysłowej. Za spuściznę industrialną uznano nie tylko fabryki, ale również obiekty towarzyszące - osiedla fabrykanckie i robotnicze, budynki administracyjne czy urządzenia hydrotechniczne na rzece Kamiennej. Obiekty poprzemysłowe, tracąc swoją podstawową funkcję związaną z przemysłem, pozostawały jeszcze do niedawna niezagospodarowane i w konsekwencji często popadały $\mathrm{w}$ ruinę. $\mathrm{W}$ ostatnich latach nadawane są im nowe funkcje. Zdecydowaną większość obiektów dziedzictwa przemysłowego zlokalizowanych w dolinie rzeki Kamiennej przekształcono w muzea dokumentujące historię rozwoju przemysłu w Staropolskim Okręgu Przemysłowym i XIX-wieczną architekturę industrialną. Część obiektów w dolinie rzeki Kamiennej uzyskała nowe, inne niż muzealne znaczenie. Pofabryczne budynki zostały także zaadoptowane na funkcje oświatowo-wychowawcze i społeczno-kulturalne. W siedzibach zarządów dawnych zakładów działają obecnie szkoły, gminne ośrodki kultury. Zachowano industrialny wygląd tych budynków, jednak ich wnętrza zmodyfikowano i dostosowano do obecnie pełnionych funkcji.

Badania ankietowe, prowadzone w 2014 roku wśród mieszkańców gmin położonych w dolinie rzeki Kamiennej, a także wśród turystów odwiedzających ten region, miały na celu poznanie opinii na temat jego atrakcyjności turystycznej, stopnia znajomości historii oraz znaczenia występującego tutaj dziedzictwa przemysłowego. Badania pokazały, że o ile wiedza mieszkańców o istotnej w przeszłości roli przemysłu na tym terenie jest znacząca, to zaledwie kilka procent ankietowanych turystów kojarzy dolinę z dawnym przemysłem.

Badania pozwalają stwierdzić, że dziedzictwo przemysłowe w dolinie rzeki Kamiennej jest słabo wyeksponowane i nie cieszy się jeszcze dużym zainteresowaniem wśród turystów. 
Ratowanie i zachowanie zabytków techniki, nie tylko zresztą w dolinie rzeki Kamiennej, ma na celu pokazanie społeczeństwu polskiej myśli technicznej dawnych czasów oraz wartości kulturotwórczych i edukacyjnych zachowanych obiektów. Ma to istotne znaczenie również dla kształtowania poczucia identyfikacji regionalnej i lokalnej ludności zamieszkującej te obszary.

\section{LITERATURA}

Balińska G., 1999, Kamienna rzeka pracujaca, przemiany krajobrazu przemystowego, Wrocław.

Bielenin K., 1958, Starożytne piece hutnicze w Zagłębiu Staropolskim, [w:] Z Otchłani Wieków: pismo poświęcone pradziejom Polski, Nr 1, Stowarzyszenie Naukowe Archeologów Polskich, Warszawa.

Biernat T., Ciupa T., 2011, Środowisko wodne Geoparku Dolina Kamiennej, „Problemy Ekologii Krajobrazu", 29, Uniwersytet Jana Kochanowskiego, Kielce, s. 151-159.

Bobiński S., 1939, Centralny Okręg Przemystowy, Towarzystwo Wydawnicze Z. Kozierkiewicz, Warszawa.

Czmuchowski A., 2013, Historia i wspótczesność na szlaku zabytków techniki Staropolskiego Zaglębia Przemystowego ze szczególnym uwzględnieniem „,Koncepcji Otwartego Muzeum Przemystu w Samsonowie”, „Nauki Społeczne”, 1 (7).

Dziemianko Z., 2007, Koszty budowy Centralnego Okregu Przemystowego, [w:] Konefał J., COP Przeszłość - Teraźniejszość - Przyszłość, Wydawnictwo Diecezjalne i Drukarnia w Sandomierzu, Stalowa Wola.

Fierla I., 1979, Geografia przemystu Polski, Państwowe Wydawnictwo Ekonomiczne, Warszawa.

Furtak M., 2014, COP Centralny Okręg Przemystowy 1936-1939, architektura i urbanistyka, Dom Wydawniczy Księży Młyn, Kraków-Łódź.

Jędrysiak T., 2011, Turystyka kulturowa w obiektach poprzemysłowych - zagadnienia ogólne, „Turystyka Kulturowa”, 6.

Kaczmarska A., Przybyłka A., 2010, Wykorzystanie potencjału przemystowego i poprzemystowego na potrzeby turystyki. Przyktad Szlaku zabytków techniki województwa ślaskiego, [w:] Krajobraz a turystyka, Prace Komisji Krajobrazu Kulturowego PTG nr 14, Komisja Krajobrazu Kulturowego PTG.

Kamińska W., Kozak A., 1993, Czynniki ksztattowania się struktur Staropolskiego Okręgu Przemystowego, [w:] Zioło Z. (red.), Problematyka okręgu przemystowego w akademickim kształceniu nauczycieli geografii, Materiały i Sprawozdania nr 26, Wydawnictwo Naukowe WSP, Kraków.

Kaptur P., 2014, Podziemne górnictwo rud żelaza w rejonie Ostrowca Świętokrzyskiego i inwentaryzacja reliktów dawnych robót górniczych, „Hereditas Minariorum”, 1.

Kowalczyk A., 2000, Geografia turyzmu, PWN, Warszawa.

Krauze J., 2012, Znad Kamiennej: Zakłady Zbrojeniowe w Skarżysku-Kamiennej w latach 1923-1939, nakładem autora, Kielce.

Kronenberg M., 2012, Wplyw zasobów dziedzictwa przemystowego na atrakcyjność turystyczna miasta. Przykład Łodzi, Wydawnictwo Uniwersytetu Łódzkiego, Łódź. 
Molenda M., 2010, Obiekty przemysłowe zagłębia staropolskiego jako produkt turystyczny regionu świętokrzyskiego, [w:] Potencjał turystyczny. Zagadnienia przestrzenne, „Zeszyty Naukowe Uniwersytetu Szczecińskiego”, 590.

Orłowski B., 2007, Krótka charakterystyka stanu techniki polskiej w Dwudziestoleciu Niepodległości, [w:] Konefał J., COP Przeszłość - Teraźniejszość - Przyszłość, Wydawnictwo Diecezjalne i Drukarnia w Sandomierzu, Stalowa Wola.

Pazdur J., 1959, Działalność Stanisława Staszica w Kielecczyźnie, Kieleckie Towarzystwo Naukowe, Kielce-Kraków.

Przazga S., 1969, Rozwój społeczno-gospodarczy Staropolskiego Okręgu Przemysłowego w latach 1960-1968, Wojewódzki Urząd Statystyczny, Kielce.

Puś W., 1997, Rozwój przemystu w Królestwie Polskim, Wydawnictwo Uniwersytetu Łódzkiego, Łódź.

Roszkowski W., 2012, COP a gospodarka II RP po kryzysie, [w:] Garbacz A., Trybuła B., Centralny Okręg Przemystowy wczoraj*dziś*jutro, Materiały z konferencji naukowej w 75. rocznicę rozpoczęcia budowy COP-u, Muzeum Regionalne w Stalowej Woli, s. 19-20.

Soja R., 2003, Mapa hydrograficzna 1:50000, Arkusz M-34-30-C Stąporków, GUGiK, Warszawa.

Szot-Radziszewska E., 2009, Postindustrialne dziedzictwo Staropolskiego Okręgu Przemysłowego w krajobrazie kulturowym Kielecczyzny: zagrożenia i szanse, „Ochrona Zabytków", 4(247), Wydawnictwo DiG, Warszawa.

Wejland A., 1992, Kwestionariusz, [w:] Sawiński Z. (red.), Podręcznik socjologicznych badań ankietowych, Warszawa.

Zieliński J., 1965, Staropolskie Zagłębie Przemysłowe, Zakład Narodowy im. Ossolińskich, Wrocław.

\title{
CONTEMPORARY SIGNIFICANCE OF THE INDUSTRIAL HERITAGE IN THE KAMIENNA RIVER VALLEY (SWIETOKRZYSKI REGION)
}

\begin{abstract}
The subject of this article is the industrial heritage in the Kamienna river valley, located in Swietokrzyski Region and its contemporary significance in the land-use. The essential part of the article devoted to contemporary functions of industrial facilities within the current socio-economic conditions is preceded by a brief description of factors and stages of industrial development in this area. In the last part, the study presents the results of surveys focused on social perception of the region's industrial past and opinions on the adaptation of its heritage to the new socio-economic conditions.
\end{abstract}

Keywords Industry, industrial heritage, Kamienna river valley, Swietokrzyski Region.

Mgr Małgorzata Dworak

Dr Paulina Tobiasz-Lis

Katedra Geografii Regionalnej i Społecznej

Wydział Nauk Geograficznych

Uniwersytet Łódzki 